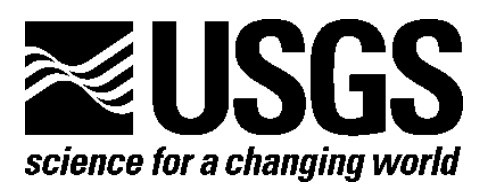

\title{
China's Rare-Earth Industry
}

By Pui-Kwan Tse

Open-File Report 2011-1042

U.S. Department of the Interior

U.S. Geological Survey 


\section{U.S. Department of the Interior \\ KEN SALAZAR, Secretary}

\section{U.S. Geological Survey \\ Marcia K. McNutt, Director}

U.S. Geological Survey, Reston, Virginia: 2011

For more information on the USGS-the Federal source for science about the Earth, its natural and living resources, natural hazards, and the environment-visit http://www.usgs.gov or call 1-888-ASK-USGS

For an overview of USGS information products, including maps, imagery, and publications, visit http://www.usgs.gov/pubprod

To order this and other USGS information products, visit http://store.usgs.gov

Suggested citation:

Tse, Pui-Kwan, 2011, China's rare-earth industry: U.S. Geological Survey Open-File Report 2011-1042, 11 p., available only online.

Any use of trade, product, or firm names is for descriptive purposes only and does not imply endorsement by the U.S. Government.

Although this report is in the public domain, permission must be secured from the individual copyright owners to reproduce any copyrighted material contained within this report. 


\section{Contents}

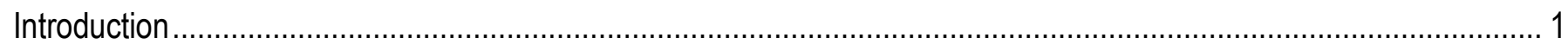

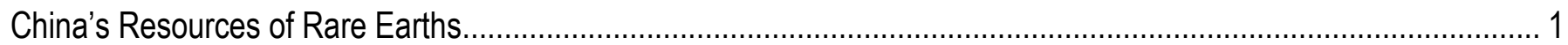

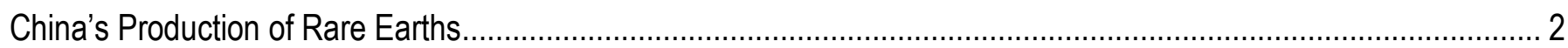

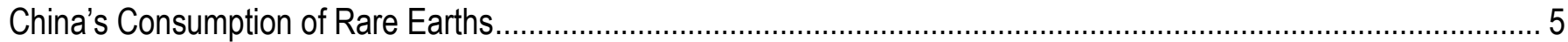

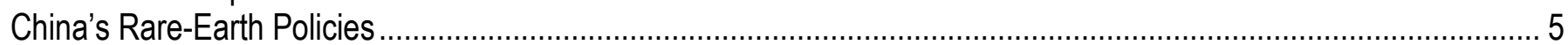

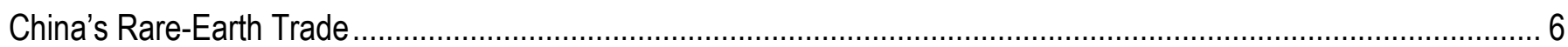

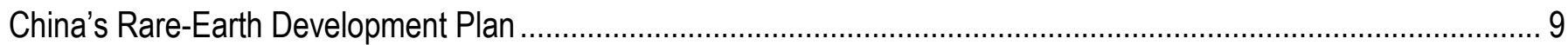

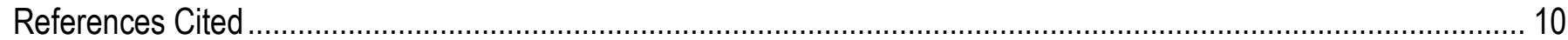

\section{Figure}

1. Graph showing global rare-earth-oxide production trends ................................................................ 3

\section{Tables}

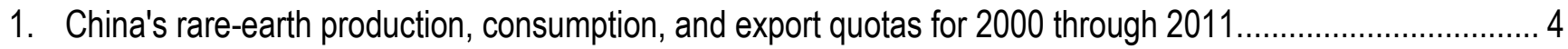

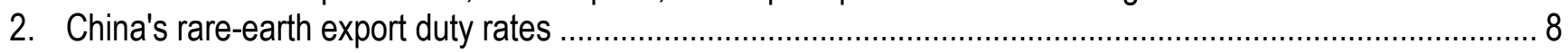




\section{Conversion Factors}

\begin{tabular}{lll}
\hline \multicolumn{1}{c}{ Multiply } & By & \multicolumn{1}{c}{ To obtain } \\
\hline Mass & \\
\hline metric ton (t, 1,000 kilograms) & 1.102 & $\begin{array}{l}\text { short ton }(2,000 \text { pounds } \\
\text { avoirdupois }) \\
\text { million short tons }\end{array}$ \\
\hline
\end{tabular}




\title{
China's Rare-Earth Industry
}

\author{
By Pui-Kwan Tse
}

\section{Introduction}

China's dominant position as the producer of over 95 percent of the world output of rare-earth minerals and rapid increases in the consumption of rare earths owing to the emergence of new cleanenergy and defense-related technologies, combined with China's decisions to restrict exports of rare earths, have resulted in heightened concerns about the future availability of rare earths. As a result, industrial countries such as Japan, the United States, and countries of the European Union face tighter supplies and higher prices for rare earths. This paper briefly reviews China's rare-earth production, consumption, and reserves and the important policies and regulations regarding the production and trade of rare earths, including recently announced export quotas.

The 15 lanthanide elements - lanthanum, cerium, praseodymium, neodymium, promethium, samarium, europium, gadolinium, terbium, dysprosium, holmium, erbium, thulium, ytterbium, and lutetium (atomic numbers 57-71) — were originally known as the rare earths from their occurrence in oxides mixtures. Recently, some researchers have included two other elements - scandium and yttrium - in their discussion of rare earths. Yttrium (atomic number 39), which lies above lanthanum in transition group III of the periodic table and has a similar 3+ ion with a noble gas core, has both atomic and ionic radii similar in size to those of terbium and dysprosium and is generally found in nature with lanthanides. Scandium (atomic number 21) has a smaller ionic radius than yttrium and the lanthanides, and its chemical behavior is intermediate between that of aluminum and the lanthanides. It is found in nature with the lanthanides and yttrium.

Rare earths are used widely in high-technology and clean-energy products because they impart special properties of magnetism, luminescence, and strength. Rare earths are also used in weapon systems to obtain the same properties.

\section{China's Resources of Rare Earths}

China is rich in rare-earth resources and produces a number of different kinds of rare-earth products. China's scientists discovered rare-earth resources in Bayan Obo in 1927 and started the production of rare-earth concentrates in 1957. After more than 8 decades of exploration, rare-earth resources have been discovered in 21 of China's Provinces and Autonomous Regions-Fujian, Gansu, Guangdong, Guangxi, Guizhou, Hainan, Henan, Hubei, Hunan, Jiangxi, Jilin, Liaoning, Nei Mongol, Qinghai, Shaanxi, Shandong, Shanxi, Sichuan, Xinjiang, Yunnan, and Zhejiang.

As of 1998, the country's total rare-earth resource (资源量) was reported to be 92 million metric tons (Mt) (Wen, 1998, p. 140). In 2009, China's Ministry of Land and Resources (MLR) reported that the country had rare-earth reserves (储量) of 18.6 Mt in rare-earth-oxide (REO) content (China National Bureau of Statistics, 2010, p. 410). 
China's reserve and resource system divides the country's minerals into reserves (储量) and resources (资源量) (China National Material and Technical Control Bureau, 1999). Reserves are divided into proved extractable reserves (可采储量) (code 111), probable extractable reserves (预可采储量) (code 121), and basic reserves (基础储量) (code 122). The discovered mineral resources are divided into measured, indicated, and inferred. Comparisons with different reserve systems are difficult and always approximate. The basic reserve (基础储量) in the Chinese reserve classification system best approximates reserves as defined by the U.S. Bureau of Mines and U.S. Geological Survey (1980) in USGS Circular 831, "Principles of a Resource/Reserve Classification for Minerals." The MLR publishes the country's reserve and resource data yearly, but these reports are not available to overseas researchers. Estimation of China's rare-earth basic reserve (基础储量) was $55 \mathrm{Mt}$ in REO (China National Material and Technical Control Bureau, 1999).

\section{China's Production of Rare Earths}

China's main rare-earth production takes place in the Provinces of Fujian, Guangdong, Jiangxi, and Sichuan and in Nei Mongol Autonomous Region. Nei Mongol accounted for between 50 percent and 60 percent of China's total rare-earth concentrate output during the past decade. Sichuan Province was the second leading rare-earth concentrate producer, accounting for between 24 percent and 30 percent of production during the past decade. The remaining output was from the Provinces of Fujian, Guangdong, and Jiangxi, which are important for their production of "heavy" rare earths (Chen, 2010; Geological Publishing House, 2010).

Between 1990 and 2000, China's production increased over 450 percent to 73,000 metric tons (t) from about 16,000 $\mathrm{t}$ (fig. 1). During the same period, production from other countries declined almost 60 percent to about 16,000 t from 44,000 t. As a result, world production increased just over 150 percent to almost 91,000 t from about 60,000 t between 1990 and 2000. Since 2000, world and Chinese production have continued to increase; by 2009, world production increased 45 percent to about 132,000 $\mathrm{t}$, and Chinese production increased 77 percent to 129,000 t. Production from other countries decreased to about 3,000 $\mathrm{t}$ in 2009 .

The volume of China's rare-earth output as a percentage of total world output increased to more than 90 percent in 2008 from 27 percent in 1990. During the past 15 years, China has supplied more than 80 percent of the world's rare earths as concentrates, intermediate products, and chemicals. Although Chinese production expanded rapidly, China's rare-earth producers reportedly have struggled to maintain profitability. Throughout the 1990s and 2000s, the Government and rare-earth producers had met and discussed ways to control production and exports as a means of conserving the country's mineral resources and protecting the environment. Nevertheless, competition among local governments and enterprises resulted in sustained high levels of production. Local governments depended upon rareearth producers to provide employment and revenue for local economic development and did not always follow the national Government's guidelines on rare earths. As a result, the country's actual output of rare-earth concentrate continued to exceed the Government's production target (China State Council, 2006). Since 2006, the Government has stepped up enforcement of its policies and regulations and shut down illegal mines in the Provinces of Guangdong, Jiangxi, and Sichuan. Consequently, production of rare earths has been approximately level during the past 5 years (table 1). 


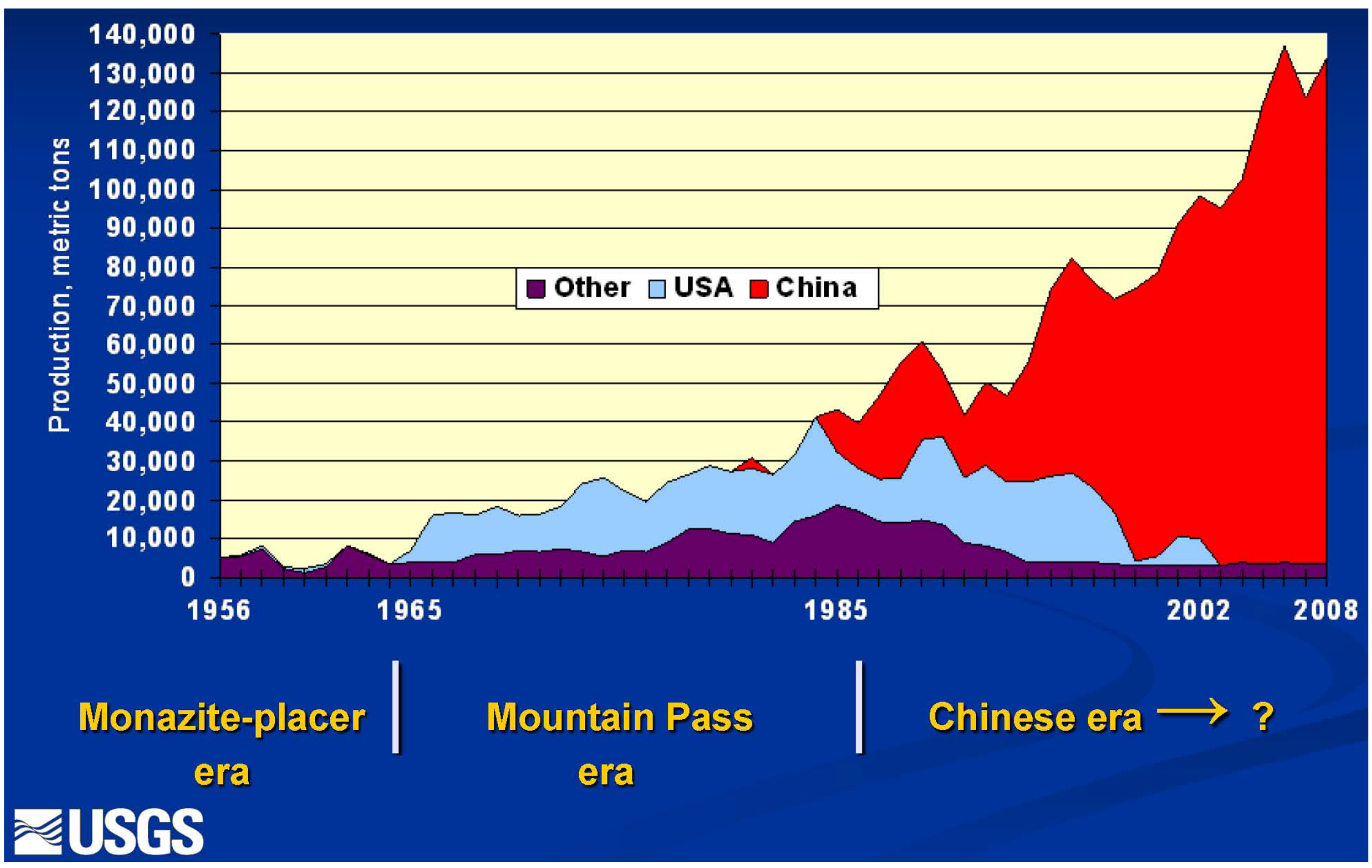

Figure 1. Global rare-earth-oxide production trends. The Mountain Pass deposit is in California, U.S.A. Graph from D.J. Cordier (U.S. Geological Survey, written commun., 2011) was updated from Haxel and others (2002, fig. 1). 
Table 1. China's rare-earth production, consumption, and export quotas for 2000 through 2011.

[In metric tons of rare-earth-oxide (REO) equivalent except as described in footnote 1. Abbreviations used: est., estimated; MIIT; China Ministry of Industry and Information Technology; MLR, China Ministry of Land and Resources; NA, not available. Sources: China Ministry of Commerce (2006, 2008a,b, 2009, $2010 \mathrm{a}, \mathrm{b}, \mathrm{c})]$

\begin{tabular}{|c|c|c|c|c|c|c|c|c|c|c|c|c|c|}
\hline & & 2000 & 2001 & 2002 & 2003 & 2004 & 2005 & 2006 & 2007 & 2008 & 2009 & 2010 & 2011 \\
\hline Production quota & MIIT & & & & & & & & & 119,500 & 110,700 & 89,200 & NA \\
\hline & MLR & 55,000 & NA & NA & NA & NA & NA & 86,620 & 87,020 & 90,180 & 87,620 & 89,200 & NA \\
\hline Production & (est.) & 73,000 & 81,000 & 88,000 & 92,000 & 98,000 & 119,000 & 133,000 & 120,000 & 125,000 & 129,000 & 120,000 & NA \\
\hline Consumption & (est.) & 19,000 & 20,000 & 22,000 & 30,000 & 34,000 & 52,000 & 63,000 & 73,000 & 67,700 & 73,000 & 77,000 & NA \\
\hline Export quota & $\begin{array}{l}\text { Domestic producers and } \\
\text { traders }{ }^{1} \\
\text { Sino-foreign joint ventures }\end{array}$ & $\begin{array}{r}47,000 \\
\text { NA }\end{array}$ & $\begin{array}{r}45,000 \\
\text { NA }\end{array}$ & $\begin{array}{l}\text { NA } \\
\text { NA }\end{array}$ & $\begin{array}{r}40,000 \\
\text { NA }\end{array}$ & $\begin{array}{r}45,000 \\
\text { NA }\end{array}$ & $\begin{array}{l}48,010 \\
17,570\end{array}$ & $\begin{array}{l}45,000 \\
16,070\end{array}$ & $\begin{array}{l}43,574 \\
16,069\end{array}$ & $\begin{array}{l}34,156 \\
15,834\end{array}$ & $\begin{array}{l}31,310 \\
16,845\end{array}$ & $\begin{array}{r}22,512^{2} \\
7,746^{4}\end{array}$ & $14,446^{3}$ \\
\hline
\end{tabular}

${ }^{1}$ Export quotas are in gross weight rather than REO content for domestic producers and traders and Sino-foreign producers in 2005 and later years.

${ }^{2}$ Total export quota for 22 domestic producers and traders.

${ }^{3}$ Export quota for 2011 is only for the first tranche for 31 domestic producers and traders and Sino-foreign joint-venture producers.

${ }^{4}$ Total export quota for Sino-foreign producers. 


\section{China's Consumption of Rare Earths}

Although China's production of rare-earth minerals increased markedly between 1990 and 2000, China's consumption of rare earths did not undergo a similar increase until after 2000. In 1990, Chinese consumption of rare earths was relatively small; however, by 2000, China's consumption had reached about 19,000 t, and world consumption was about 91,000 t. If production and consumption were about equal, then consumption was about 72,000 t by the rest of the world. From 2000 to 2009, China's consumption of rare earths increased rapidly; by 2005, China's consumption had reached almost 52,000 $\mathrm{t}$ and, by 2009, China's rare earth consumption was 73,000 t, about 380 percent higher than in 2000 . The 2009 production and consumption data suggest that consumption of rare earths by the rest of the world has decreased to about 59,000 t. Given the rapid development of new products using rare earths, this seems unlikely and suggests that some production, possibly 20,000 t to 40,000 t, has not been accounted for in publicly available production statistics.

In China, the magnet sector accounted for about 30 percent of the total rare-earth use followed by metallurgical, 15 percent; chemical and petroleum, 10 percent; ceramics and glass, 10 percent; agriculture and textile, 10 percent; hydrogen storage, 9 percent; and others, 16 percent. In 1987, rareearth applications in the new material industry, which includes the production of such products as catalysts, magnets, phosphors, and polishing powder, accounted for about 1 percent of the total mineral consumed; by 2008, however, it increased to more than 53 percent. In China, rare-earth consumption by the new material sector is expected to increase faster than the other traditional industrial sectors.

\section{China's Rare-Earth Policies}

In 1990, the Chinese Government declared rare earths to be a protected and strategic mineral. As a consequence, foreign investors are prohibited from mining rare earths and are restricted from participating in rare-earth smelting and separation projects except in joint ventures with Chinese firms. All projects for rare-earth mining and smelting, whatever their size, required approval from the State Development and Planning Commission (SDPC) (formerly the State Planning Commission), which included the Rare-Earth Office. Sino-foreign joint-venture projects had to be approved by both SDPC and the Ministry of Commerce (MOC); prior to 2003, the Ministry of Foreign Trade and Economic Cooperation (MOFTEC) approved Sino-foreign joint ventures in rare earths.

Since the early 1990s, MLR has been responsible for developing production plans for the country's strategic commodities, including rare earths. The plans include overall production quotas, as well as quotas for individual Provinces. Provincial governments are responsible for managing their Province's allocated quota and for assigning output quotas to individual mining companies. Despite production quotas, the output of rare earths and other commodities has been much higher than the Government's target. In addition, a significant amount of the over-quota production was by miners who worked without proper mining licenses and who used obsolete mining technology that caused significant environmental damage, especially in the Provinces of Guangdong, Jiangxi, and Sichuan.

In 2008, the Rare-Earth Office was transferred to the Ministry of Industry and Information Technology (MIIT), which started issuing a rare-earth production quota for the country. The MIIT quota was much higher than the one set by MLR (table 1); this caused confusion among rare-earth producers. During 2008 and 2009, there was an apparent lack of communication between the MIIT and MLR about which agency should assign the country's rare-earth production quota. The MIIT rare-earth production quota appeared to be more reflective of rare-earth output of the country (table 1). This confusion came to an end in 2010 when both agencies set the same rare-earth production quota. 


\section{China's Rare-Earth Trade}

In addition to setting production quotas for rare earths, China also sets quotas on the amount of rare earths that can be exported. These quotas are released in two tranches. Before 2003, rare-earth export quotas were determined by the SDPC and were distributed by the State Economic and Trade Commission (SETC), and the MOFTEC issued the licenses. After the SETC and MOFTEC were abolished, the MOC took over responsibility for the issuance and distribution of export licenses. Separate export quotas are set for domestic rare-earth producers and for Sino-foreign joint-venture rareearth producers. Sino-foreign joint-venture rare-earth companies are allowed to export their own products under a licensing system.

Owing to the increase in domestic demand, the Government has gradually reduced the export quota during the past several years. In 2006, the Government allowed 47 domestic rare-earth producers and traders and 12 Sino-foreign rare-earth producers to export rare-earth products. In 2009, only 23 domestic rare-earth producers and traders and 11 Sino-foreign rare-earth producers were authorized to export rare-earth products. The number of permitted exporters was reduced to 22 domestic rare-earth producers and traders and 10 Sino-foreign rare-earth producers in 2010 and to 22 domestic rare-earth producers and traders and 9 Sino-foreign rare-earth producers in 2011.

In addition to setting export quotas, the Government has encouraged the export of high-value downstream products and discouraged the export of raw material. The desire to encourage exports of finished products is reflected by a change in the way the export quota was released. Initially the export quota was released as rare-earth-oxide equivalent. During the past 6 years, the Government has specified the tonnage limit of specific rare-earth products that Sino-foreign joint ventures are allowed to export, such as oxides, salts, or metal. However, until June 2010, there was no specification by product form for domestic rare-earth producers and traders. Beginning in July 2010, the MOC ceased issuing separate export quotas to domestic and Sino-foreign joint-venture rare-earth producers and ceased specification by product for joint-venture producers (China Ministry of Commerce, 2006, 2008a,b, 2009, 2010a,b,c).

Between 2005 and 2007, the Government quota allocated more than 40,000 t of rare-earth production to domestic producers and traders and about 16,000 t to Sino-foreign joint-venture producers (table 1). In 2008, the Government reduced the rare-earth export quota for domestic rare-earth producers and traders by 21.6 percent from that of 2007; in 2009, it reduced the quota by an additional 2.5 percent. The rare-earth export quota for Sino-foreign joint-venture producers remained at the level of 16,000 $\mathrm{t}$ in 2008 and 2009. In 2010, the Government allocated the first tranche of the rare-earth export quota, a total of 22,282 $\mathrm{t}(16,304 \mathrm{t}$ to domestic and 5,978 $\mathrm{t}$ to Sino-foreign); this was more than the total of $21,728.1 \mathrm{t}$ $(15,043 \mathrm{t}$ to domestic and 6,685.1 $\mathrm{t}$ to Sino-foreign) that was allocated for the first tranche for 2009. In the second tranche of the export quota allocated in July 2010, the Government allocated a total of 7,976 $\mathrm{t}(6,208 \mathrm{t}$ to domestic and $1,768 \mathrm{t}$ to Sino-foreign), compared with a total of $26,427 \mathrm{t}(16,267 \mathrm{t}$ to domestic and 10,160 t to Sino-foreign) in 2009. The rare-earth export quota in 2010 was 37.1 percent less than in 2009. In 2011, the Government established a 14,446-t rare-earth export quota (10,762 $\mathrm{t}$ to domestic and 3,684 to Sino-foreign), which was about 35 percent less than the first-tranche quota for 2010 (China Ministry of Commerce, 2009, 2010a,b,c).

In addition to issuing production and export quotas, China taxes mineral production to raise revenue and to regulate the mineral industries. In the 1990s, the Government encouraged enterprises to export their products by refunding the value-added tax that producers paid on exported products. In early 2000, owing to increased domestic consumption, the Government reduced the export rebate for many strategic commodities. In 2005, the rebate on exported rare earths was eliminated, and trade of rare-earth concentrate was banned. In 2007, the Government introduced an export duty on rare-earth 
products to restrict the export of products that consume large amounts of energy to produce in order to protect the domestic supply of strategic minerals (table 2).

In 2008, China exported a total of 54,963 t (gross weight) of rare-earth products, including $41,349 \mathrm{t}$ of rare-earth oxides; 5,739 $\mathrm{t}$ of rare-earth salts; 4,550 $\mathrm{t}$ of rare-earth metals; 2,390 $\mathrm{t}$ of rare-earth alloys; and 935 t of other rare-earth products. In 2009, owing to the global financial recession, the demand for rare-earth products was weak, especially from Japan; therefore, China's rare-earth exports decreased to 43,918 t, which included 32,084 t of rare-earth oxides; 6,082 t of rare-earth salts; 3,271 t of rare-earth metals; 2,075 t of rare-earth alloys; and $406 \mathrm{t}$ of other rare-earth products (Yin, 2010). 
Table 2. China's rare-earth export duty rates.

[In percentage. Abbreviation used: NA, not available. Sources: China Customs Import and Export Tariff Department (2007-2011)]

\begin{tabular}{|c|c|c|c|c|c|}
\hline \multirow{2}{*}{ Commodity } & \multicolumn{5}{|c|}{ Export duty rate (\%) } \\
\hline & 2007 & 2008 & 2009 & 2010 & 2011 \\
\hline Yttrium oxide & 10 & 25 & 25 & 25 & 25 \\
\hline Lanthanum oxide & 10 & 15 & 15 & 15 & 15 \\
\hline Cerium oxide, hydroxide, carbonate, and others & 10 & 15 & 15 & 15 & 15 \\
\hline Praseodymium & NA & NA & NA & NA & NA \\
\hline Neodymium oxide & 10 & 15 & 15 & 15 & 15 \\
\hline Europium and its oxide & 10 & 25 & 25 & 25 & 25 \\
\hline Gadolinium & NA & NA & NA & NA & NA \\
\hline Terbium and its oxide, chloride, and carbonate & 10 & 25 & 25 & 25 & 25 \\
\hline Dysprosium oxide, chloride, and carbonate & 10 & 25 & 25 & 25 & 25 \\
\hline Holmium & NA & NA & NA & NA & NA \\
\hline Erbium & NA & NA & NA & NA & NA \\
\hline Thulium & NA & NA & NA & NA & NA \\
\hline Ytterbium & NA & NA & NA & NA & NA \\
\hline Lutetium & NA & NA & NA & NA & NA \\
\hline Other rare-earth oxide & 10 & 15 & 15 & 15 & 15 \\
\hline Mixed rare-earth chlorides and fluorides & 10 & 15 & 15 & 15 & 15 \\
\hline Mixed rare-earth carbonates & 10 & 15 & 15 & 15 & 15 \\
\hline $\begin{array}{l}\text { Mixed rare-earth, yttrium, and scandium } \\
\text { compounds and metals (including battery grade) }\end{array}$ & 10 & 25 & 25 & 25 & 25 \\
\hline Non-mixed rare-earth carbonates & 10 & 15 & 15 & 15 & 15 \\
\hline Rare-earth ore & 10 & 10 & 15 & 15 & 15 \\
\hline \multicolumn{6}{|l|}{ Metals: } \\
\hline Lanthanum & NA & NA & NA & NA & 25 \\
\hline Cerium & NA & NA & NA & NA & 25 \\
\hline Neodymium & 10 & 15 & 15 & 15 & 15 \\
\hline Dysprosium & NA & NA & NA & 25 & 25 \\
\hline Other mixed metals & NA & NA & NA & 25 & 25 \\
\hline
\end{tabular}




\section{China's Rare-Earth Development Plan}

According to China's draft rare-earth development plan, annual rare-earth production may be limited to between 130,000 $\mathrm{t}$ and 140,000 $\mathrm{t}$ (REO) during the period from 2009 to 2015. The export quota for rare-earth products may be about 35,000 t (REO), and the Government may allow 20 domestic rare-earth producers and traders to export rare earths. The plan was proposed to control the export of rare-earth primary products, such as rare-earth salts, and to encourage the export of new rare-earth downstream material products. The Government will not ban the export of dysprosium and terbium but will limit the volume of export for these two elements. The Government will not approve any new rareearth separation projects before 2015. To protect rare-earth resources, rare-earth producers will be required to have a minimum mine output capacity of 300,000 metric tons per year ( $\mathrm{t} / \mathrm{yr}$ ) of ore for light rare earths and 3,000 t/yr (REO) for ion-adsorption rare earths. The Government will ban monazite mining if the monazite contains radioactive elements. For rare-earth separation, producers will be required to have a separation output capacity of 8,000 t/yr (REO) of mixed rare earths, 5,000 t/yr (REO) of bastnaesite, and 3,000 t/yr (REO) of ion-adsorption rare earths. Metal smelting producers must have an output capacity of $1,500 \mathrm{t} / \mathrm{yr}$.

Rare-earth producers will be required to meet the environmental emission standards; otherwise, they will be shut down (China Ministry of Environmental Protection, 2011).

The government of Nei Mongol Autonomous Region granted approval to Baotou Iron and Steel and Rare Earths Corp. to stockpile up to 30,000 t of rare-earth concentrates in Baotou. This will allow the company to increase the recovery of rare earths to 50 percent from 25 percent in the separation process (China Ministry of Industry and Information Technology, 2010; Wang, 2010).

During the past several years, the Government has continued to urge rare-earth producers to merge into large groups and to eliminate duplicate projects. Rare-earth producers realized that consolidation could benefit the rare-earth sector in China and would avoid unnecessary competition among themselves and associated financial losses. Dingnan Dahua New Materials Co. Ltd., Ganxian Hongjin Rare Earth Co. Ltd., and Minmetals Nonferrous Metals Co. Ltd. formed a joint-venture company, Minmetals Ganzhou Rare Earth Co. Ltd., to process rare-earth resources in Ganzhou, Jiangxi Province, in 2008. Most of China's ion-adsorption rare earths are located in Ganzhou. There were 88 rare-earth producers in Ganzhou, and 90 percent of them ceased their operations because of weak prices. Jiangxi Province had a reserve of 2.3 Mt of the ion-adsorption rare earths. Minmetals Ganzhou Rare Earth had a rare-earth separation capacity of 8,500 t/yr and planned to expand the separation capacity to 13,500 t/yr within 5 years. The joint venture also planned to develop value-added rare-earth products for the aerospace and electronics sectors.

Aluminum Corporation of China (Chinalco) signed an agreement with the government of Jiangxi Province to allow the company to consolidate the local nonferrous metals producers in the Province and to take shares of Jiangxi Rare Earth and Rare Metals Tungsten Group Co. Ltd. (JXTC). Chinalco and JXTC formed a joint-venture company, in which Chinalco held 51 percent of the shares, to manufacture nickel-cobalt products. JXTC was a leading producer of rare-earth products in Jiangxi Province. In 2003, Minmetals and JXTC formed a joint venture to produce tungsten products. Minmetals planned to acquire rare-earth resources in the Provinces of Guangdong and Hunan. Minmetals also planned to become the leading downstream rare-earth-product producer in the country. Chinalco and Minmetals are likely to compete for Jiangxi's rare-earth resources (China Mining and Metals Weekly, 2010). 


\section{References Cited}

Chen Zhanheng, 2010, Outline on the development and policies of China rare earth industry: Beijing, Office of the Chinese Society of Rare Earths, April 7. (Accessed May 26, 2010, at http://www.cs-re.org.cn/rebbs/viewthread.php?tid=1706\&highlight.)

China Customs Import and Export Tariff Department, 2007-2011, Customs import and export tariff of the People's Republic of China: Beijing, China, Economic Daily Press, volumes are separately paged. (In Chinese.)

China Mining and Metals Weekly, 2010, Chinalco, Jiangxi Rare Earth establish nickel-cobalt JV: Interfax Information Services, v. 9, no. 16, p. 3.

China Ministry of Commerce, 2006, Ministry of Commerce 2006 announcement of industrial export quota for foreign investors: Beijing, China, China Ministry of Commerce Circular 107, February 7, 2 p. (In Chinese.)

China Ministry of Commerce, 2008a, Ministry of Commerce 2008 first batch of general export quota of rare earths announcement: Beijing, China, China Ministry of Commerce, January 15, 2 p. (In Chinese.)

China Ministry of Commerce, 2008b, Ministry of Commerce 2008 industrial export quota for foreign investors announcement: Beijing, China, China Ministry of Commerce, February 18, 2 p. (In Chinese.)

China Ministry of Commerce, 2009, 2010 first batch of rare-earth export quota: Beijing, China, China Ministry of Commerce Circular 147, December 29, 2 p. (In Chinese.)

China Ministry of Commerce, 2010a, 2010 first batch of industrial export quota for foreign investors: Beijing, China, China Ministry of Commerce Circular 106, February 23, 2 p. (In Chinese.)

China Ministry of Commerce, 2010b, 2010 second batch of rare-earth export quota: Beijing, China, China Ministry of Commerce, July 7, 2 p. (In Chinese.)

China Ministry of Commerce, 2010c, 2011 first batch of rare-earth export quota: Beijing, China, China Ministry of Commerce, December 28, 2 p. (In Chinese.)

China Ministry of Environmental Protection, 2011, Emission standards of pollutants from rare earths industry GB 26451-2011: Beijing, China, China Ministry of Environmental Protection Standard GB 26451-2011, January 24, 13 p. (In Chinese.)

China Ministry of Industry and Information Technology, 2010, Requirement of rare earth industry entrance announcement: Beijing, China, China Ministry of Industry and Information Technology, May 12, 5 p. (In Chinese.)

China National Bureau of Statistics, 2010, China statistical yearbook, 2009: Beijing, China, China Statistics Press, 1,032 p. (In Chinese.)

China National Material and Technical Control Bureau, 1999, Classification for resources/reserves of solid fuels and mineral commodities GB/T 17766-1999: Beijing, China, China National Material and Technical Control Bureau Standard GB/T 17766-1999, 9 p. (In Chinese.)

China State Council, 2006, Instruction for mineral resource development: Beijing, China, China State Council Circular 108, December 31, 5 p. (In Chinese.)

Geological Publishing House, 2010, Rare metal and rare earth mining sector, in China mining history: Beijing, China, Geological Publishing House, p. 449. (In Chinese.)

Haxel, G.B., Hedrick, J.B., and Orris, G.J., 2002, Rare earth elements--Critical resources for high technology: U.S. Geological Survey Fact Sheet 087-02, 4 p., available at http://pubs.usgs.gov/fs/2002/fs087-02/.

U.S. Bureau of Mines and U.S. Geological Survey, 1980, Principles of a resource/reserve classification for minerals: U.S. Geological Survey Circular 831, 5 p. 
Wang Huachun, 2010, [The leading enterprise-Baogang Rare Earth]: China Metal Bulletin, no. 12, p. 36-37. (In Chinese.)

Wen Lu, 1998, Chinese industrial minerals-Rare earths: Surrey, United Kingdom, Industrial Minerals Information Ltd., $210 \mathrm{p}$.

Yin Jianhua, 2010, [Rare earth market is expected to become better]: China Metal Bulletin, no. 8, p. 24-25. (In Chinese.) 